\title{
The Effects of Using Microsoft Power Point on EFL Learners' Attitude and Anxiety
}

Case Study of Two Master Students of Didactics of English as a Foreign Language, Djillali Liabes University, Sidi Bel Abbes, Algeria

\author{
Boualem Benghalem \\ Djillali Liabes University,Sidi Bel Abbes,Algeria \\ Laboratoire critique et étude littéraires linguistique \\ B.p No 89 Sidi Bel Abbes 22000, Algeria \\ E-mail: benghalemist@gmail.com
}

Doi:10.7575/aiac.alls.v.6n.6p.1

URL: http://dx.doi.org/10.7575/aiac.alls.v.6n.6p.1
Received: 24/05/2015

Accepted: 17/08/2015

\begin{abstract}
This study aims to investigate the effects of using ICT tools such as Microsoft PowerPoint on EFL students' attitude and anxiety. The participants in this study were 40 Master 2 students of Didactics of English as a Foreign Language, Djillali Liabes University, Sidi Bel Abbes Algeria. In order to find out the effects of Microsoft PowerPoint on EFL students' attitude and anxiety, two main research tools were employed in this study: a questionnaire that was addressed to 40 Master 2 students of Didactics of English as a Foreign Language and an interview for 10 participants, randomly selected from the forty participants who answered the questionnaire. After the data had been analysed, the results revealed a positive attitude and low anxiety among students towards Microsoft PowerPoint. These concluding results promote the use of ICT and encourage EFL teachers to use these tools in the most beneficial way to improve students' level of English and motivate them.
\end{abstract}

Keywords: Information and Communication Technology (ICT), attitude, anxiety, English as foreign language, teaching, learning

\section{Introduction}

Educational technology and Information Communication Technology (ICT) provide many benefits for education and especially for the acquisition and application of English Language skills (listening, speaking, reading and writing) and grammar in EFL classroom. ICT is an acronym that stands for Information Communication Technology. However, apart from explaining a contraction, there is not a universally accepted definition of ICT, because the concepts, methods and applications involved in ICT are constantly evolving on an almost daily basis.

Since ICT was introduced in the West, students have benefited from educational technology. This leads to the need to investigate whether Algerian students are also getting the benefits of educational technology and ICT and progressing on balance with students in other parts of the world. Strategies have been designed to equip teachers with the knowledge and skills to use technology effectively in the classroom. Information Technology (IT) is also introduced as a subject course offered by teachers in Algerian Universities. Language instructors can also utilize Power Point in language classrooms as an effective complement to, or as a substitute for traditional textbook teaching. PowerPoint group projects can give learners the opportunity to work together toward a common group goal while using their language skills creatively.

This study involved the use of Microsoft Power Point to learn the English language. The participants of this study were Master 2 students of Didactics of English as a Foreign Language, Djillali Liabes University, Sidi Bel Abbes. The objective of this study were to determine students' attitude and to evaluate students' anxiety when Microsoft Power Point is used in EFL classroom. This research aimed to address the following research questions:

- What are the students' attitudes toward lessons that are presented by Microsoft PowerPoint to learn English?

- Do students feel anxious when lessons are presented by Microsoft PowerPoint to learn English?

The study was made up to test the following hypotheses:

- EFL students' attitude is positive when lessons are presented by Microsoft PowerPoint EFL students are less anxious when lessons are presented by Microsoft Power Point

\section{Literature review}

\subsection{Attitude and Language Learning}

Thomas (1971) views attitude as "a complex of feelings, desires, fears, convictions, prejudices or other tendencies that have given a set of readiness to act because of varied experience." According to Noor Zainab (2005), attitude is thought 
to provide answers to why some students avoid while others approach educational tasks. Noor Zainab (2005) gave an example that "if students develop positive attitudes towards learning English language, they presumably can enhance their favourable attitudes towards learning the language which in turn may lead to successful achievement." Hedge (2000) points out that, "a learner who has generally negative attitudes towards learning English will have a high affective filter and the task for the teacher will be substantial."

Teachers also can help in changing students' attitude to learn a language. Disick (1972) as cited in Noor Zainab (2005) suggests that "attitudes towards second language learning can be improved if teachers seek to promote their students' needs and interests."

\subsection{Anxiety and Language Learning}

Anxiety can be defined as "a state of uneasiness and apprehension or fear caused by the anticipation of something threatening" (Koba, Ogawa and Wilkinson, 2000). In addition, Spielberger (1972) defined anxiety as :

Unpleasant emotional state or condition, which is characterised by subjective feelings of tension, apprehension, and worry, and by activation or arousal of the autonomic nervous system.

In general, anxiety includes tension, nervousness, fear or worry and is a rather negative or unfavourable feeling. Von Wörde (2003) believes that both foreign and second language learners experience language anxiety and poses potential problems as it can interfere with the acquisition, retention and production of the new language. High levels of anxiety could prevent a student from trying in the learning process.

Teachers play an important role in reducing student anxiety. Von Wörde (2003) found that, "teachers who provide a supportive and understanding environment, who employ non-threatening teaching methods, and who use appealing and relevant topics seem to enhance the foreign language experience."

\subsection{Educational Technology and ICT in Algeria}

As Kennewell (2004) argues, the term ICT covers all aspects of computers, networks (including the Internet) and certain other devices with information storage and processing capacity such as calculators, mobile phones and automatic control devices. ICT is an acronym that stands for Information Communications Technology.

According to Kennewell (2004), ICT resources are broadly classified as follow:

- Hardware: The equipment, such as a PC or interactive whiteboard;

- Software: The stored instructions, which enable the hardware to operate automatically, together with the information that it stores and processes, such as a word processing program and the documents produced using it

- Media: The materials that carry data and programs, such as floppy or hard disks.

- Services: Combinations of hardware, software and human resources that enable users to achieve more than they could with hardware and software alone, such as the Internet.

Algeria is encouraging and fostering the use of ICT to enhance the development process in general and the development of the educational system in particular, paving the road for an ICT policy framework along with an implementation strategy (Hamdy, 2007).

According to Hamdy (2007), the government is committed to set forth a policy for the integration of ICT within the educational system. The reform of the educational process and inclusion of ICT with a set structure was formally included in the country's formal ICT policy in June 2002 with an allocation of three billion dinar. Some Algerian universities have computer labs and Internet access for faculty, students, and administration in addition to the availability of digital libraries. Each university has its own ICT policy to accelerate the educational process and offer better learning opportunities in virtual universities and with distance and open learning.

\subsection{Using Power Point in EFL Classroom}

As Radanov (2008) explains, "PowerPoint is a type of presentation software that allows one to show coloured text and images with simple animation and sound". This tool can be shown on a computer screen or using a projector with a large screen for the whole class who can view the same presentation at the same time. PowerPoint has many features, which make it a useful classroom tool. It can save teachers time because the materials that are produced for PowerPoint can be reused many times. PowerPoint also allows teachers to vary their teaching methods and break the routine (Ahmed, 2005). Moreover, Steele \& Johnson (n.d) note that using PowerPoint's big screen allows all learners (at the front and back of the class) to see what is being introduced. They argue that, when used appropriately, it can enhance the teacher's instruction and learners' motivation. Of course, teachers must also be aware of potential disadvantages of using PowerPoint. The use of presentation software encourages use of all four skills. Fisher (2003) explains that PowerPoint "can be used for initial teaching, for practice and drilling, for games, for reviews, and for tests."

\section{Methodology}

To allow the investigation of students' perceptions of the use of Microsoft Power Point, the study was based on mixed model research paradigm. The choice of this research design was pointed by the aim of the study and also the type of data to be analysed and discussed. The most important material used in this study was obtained from the closed-form questionnaire responses of the participants along with their responses to the open-form questionnaire administered for both students. 
The respondents for this study were 40 LMD Master 2 students of Didactics of English as Foreign Language in the Djillali Liabes University Sidi Bel Abbes, Faculty of Letters, Languages and Arts. They usually have few teachers who use power point to present their lessons. At that particular stage of the study, the choice of participants was based on some standards, which make the selection ideal. First, they are typical EFL Algerian learners. Second, they are students at Djillali Liabes University and consequently are more convenient in location to the researcher in terms of access and delivery of the survey. Third, they are particularly exposed to ICT in general and the use of Microsoft Power Point by few teachers. Finally, it seems likely that by fifth year of their studies in the faculty and after a long-term exposure to mandatory foreign language instructions in secondary and high schools prior to their study at university. The students' academic level is ideal for this study because they have enough experience to propose some helpful insights about the use of Microsoft Power Point in EFL classroom.

The questionnaire was distributed for the participants during class sessions, after a brief explanation about the nature of the study and its major implication in the LMD system. They were agreed to have enough time to give back the answers to the researcher himself. Following the semi-structured format, the interviews with 10 participants were conducted in an informal manner (English or Algerian Arabic).

\section{Results and Discussions}

\subsection{Participants}

The questionnaire used in this study was distributed to 40 Master 2 students of didactics of English foreign language at Djillali Liabes University Sidi Bel Abbes. In this study, the numbers of male and female students are not equally represented, as there are 7 male and 33 female respondents between the age of 21 and 46 years old as shown in the following table:

Table 4.1 Gender of the Participants

\begin{tabular}{lll}
\hline & Number & Percentage \\
Female & 33 & $82.5 \%$ \\
Male & 7 & $17.5 \%$ \\
& Total $=40$ & $100 \%$ \\
\hline
\end{tabular}

\subsection{Participants' Attitude towards Using Microsoft Power Point}

Table 4.2 was devoted to seek participants' attitude towards using Microsoft Power Point; four items were designed for this purpose. It shows the results given by the participants determined if they have positive or negative attitude.

Table 4.2 Participants' Attitude towards Using Microsoft Power Point

\begin{tabular}{|c|c|c|c|c|c|c|c|c|c|c|c|c|c|c|}
\hline \multirow[t]{2}{*}{ Statements } & \multicolumn{2}{|c|}{$\begin{array}{l}\text { Strongly } \\
\text { agree }\end{array}$} & \multicolumn{2}{|c|}{ agree } & \multicolumn{2}{|c|}{$\begin{array}{l}\text { Total } \\
(\mathrm{SA}+\mathrm{A})\end{array}$} & \multicolumn{2}{|c|}{ undecided } & \multicolumn{2}{|c|}{ Disagree } & \multicolumn{2}{|c|}{$\begin{array}{l}\text { Strongly } \\
\text { disagree }\end{array}$} & \multicolumn{2}{|c|}{$\begin{array}{l}\text { Total } \\
(\mathrm{SD}+\mathrm{D})\end{array}$} \\
\hline & $\mathrm{N}^{\circ}$ & $\%$ & $\mathrm{~N}^{\circ}$ & $\%$ & $\mathrm{~N}^{\circ}$ & $\%$ & $\mathrm{~N}^{\circ}$ & $\%$ & $\mathrm{~N}^{\circ}$ & $\%$ & $\mathrm{~N}^{\circ}$ & $\%$ & $\mathrm{~N}^{\circ}$ & $\%$ \\
\hline $\begin{array}{l}\text { I believe I can use } \\
\text { Microsoft } \\
\text { PowerPoint to } \\
\text { improve my } \\
\text { language skills. }\end{array}$ & 25 & 62,5 & 10 & 25 & 35 & 87,5 & 5 & 12,5 & 0 & 0 & 0 & 0 & 0 & 0 \\
\hline $\begin{array}{l}\text { It is boring to only } \\
\text { listen to my } \\
\text { lecturer in normal } \\
\text { English class. }\end{array}$ & 6 & 15 & 21 & 52,5 & 27 & 67,5 & 2 & 5 & 0 & 0 & 11 & 27,5 & 11 & 27,5 \\
\hline $\begin{array}{l}\text { Microsoft Power } \\
\text { Point makes it easy } \\
\text { for me to learn } \\
\text { English. }\end{array}$ & 33 & 82,5 & 7 & 17,5 & 40 & 100 & 0 & 0 & 0 & 0 & 0 & 0 & 0 & 0 \\
\hline $\begin{array}{l}\text { I am not interested } \\
\text { to use Microsoft } \\
\text { PowerPoint in } \\
\text { doing a } \\
\text { presentation. }\end{array}$ & 2 & 5 & 2 & 5 & 4 & 10 & 5 & 12,5 & 7 & 17,5 & 24 & 60 & 31 & 77,5 \\
\hline
\end{tabular}

In response to the first statement, "I believe I can use Microsoft PowerPoint to improve my language skills", $62.5 \%$ of the participants strongly agreed, $25 \%$ agreed and only $12.5 \%$ were undecided. The next statement was aimed to seek 
participants' attitude toward a classroom where there is no use of technology. A total of $67.5 \%$ agreed with the statement "It is boring to only listen to my lecturer in normal English class" while a group of 27.5\% disagreed and 5\% were undecided. All the participants $(100 \%)$ found that Microsoft PowerPoint had an easy feature of facilitating work when mistakes occur and need to be corrected. A high percentage of $77.5 \%$ disagreed with the last statement "I am not interested to use Microsoft PowerPoint in doing a presentation" while a minority of 5\% strongly agreed, 5\% agreed, however, $12 \%$ of the participants were undecided.

\subsection{Anxiety Level of Participants towards Using Microsoft Power Point}

The final part of the questionnaire was designed to determine the anxiety level of participants towards the use of Microsoft Power point in EFL classroom. Three items were designed concerning this regard and the table 3.5 shows the ratings used to determine high and low anxiety of the respondents.

Table 4.3 shows that in response to the statement "I become anxious when my teacher uses a Microsoft PowerPoint presentation", $15 \%$ strongly agreed, $12.5 \%$ agreed while $32.5 \%$ disagreed, $27.5 \%$ strongly disagreed while $12.5 \%$ were undecided.

Almost all the participants (97.5\%) agreed with the statement "I feel very disappointed when my Microsoft Power Point presentation does not work" $82.5 \%$ of the participants strongly agreed while $15 \%$ agreed. An amount of $75 \%$ of the respondents agreed with the final statement "After the training provided, I felt less anxious when I was asked to prepare a Microsoft Power Point presentation."62.5\% of the participants strongly agreed, 2.5\% agreed whereas $17.5 \%$ disagreed, $2.5 \%$ strongly disagreed and $5 \%$ were undecided.

Table 4.3 Anxiety Level of Participants towards Using Microsoft Power Point.

\begin{tabular}{|c|c|c|c|c|c|c|c|c|c|c|c|c|c|c|}
\hline \multirow[t]{2}{*}{ Statements } & \multicolumn{2}{|c|}{$\begin{array}{l}\text { Strongly } \\
\text { Agree }\end{array}$} & \multicolumn{2}{|c|}{ Agree } & \multicolumn{2}{|c|}{$\begin{array}{l}\text { Total } \\
(\mathrm{SA}+\mathrm{A})\end{array}$} & \multicolumn{2}{|c|}{ Undecided } & \multicolumn{2}{|c|}{ Disagree } & \multicolumn{2}{|c|}{$\begin{array}{l}\text { Strongly } \\
\text { Disagree }\end{array}$} & \multicolumn{2}{|c|}{$\begin{array}{l}\text { Total } \\
(\mathrm{SD}+\mathrm{D})\end{array}$} \\
\hline & $\mathrm{N}^{\circ}$ & $\%$ & $\mathrm{~N}^{\circ}$ & $\%$ & $\mathrm{~N}^{\circ}$ & $\%$ & $\mathrm{~N}^{\circ}$ & $\%$ & $\mathrm{~N}^{\circ}$ & $\%$ & $\mathrm{~N}^{\circ}$ & $\%$ & $\mathrm{~N}^{\circ}$ & $\%$ \\
\hline $\begin{array}{l}\text { I become anxious when } \\
\text { my teacher uses a } \\
\text { Microsoft PowerPoint } \\
\text { presentation. }\end{array}$ & 6 & 15 & 5 & 12,5 & 11 & 27,5 & 5 & 12,5 & 13 & 32,5 & 11 & 27,5 & 24 & 60 \\
\hline $\begin{array}{l}\text { I feel very disappointed } \\
\text { when Microsoft Power } \\
\text { Point presentation does } \\
\text { not work. }\end{array}$ & 33 & 82,5 & 6 & 15 & 39 & 97,5 & 1 & 2,5 & 0 & 0 & 0 & 0 & 0 & 0 \\
\hline $\begin{array}{l}\text { After the training } \\
\text { provided, I felt less } \\
\text { anxious when I was } \\
\text { asked to prepare a } \\
\text { Microsoft Power Point } \\
\text { presentation. }\end{array}$ & 29 & 72,5 & 1 & 2,5 & 30 & 75 & 2 & 5 & 7 & 17,5 & 1 & 2,5 & 8 & 20 \\
\hline
\end{tabular}

\subsection{Discussion of the Participants' Attitude Findings}

In general, the majority of the participants (87.5\%) had a positive attitude towards using Microsoft PowerPoint to improve the English language skills (listening, speaking writing and reading) however 12.5\% were neutral. This positive attitude of most participants indicate that there is a shift of the learning style since most participants (67.5\%) replied that the lecture presented without the use of technology is boring. However, a small proportion (27.5\%) still preferred the old method of conventional white board and marker. This is expected because learning style differs from one learner. Some students appreciate the use of technology and others are still techno phobic.

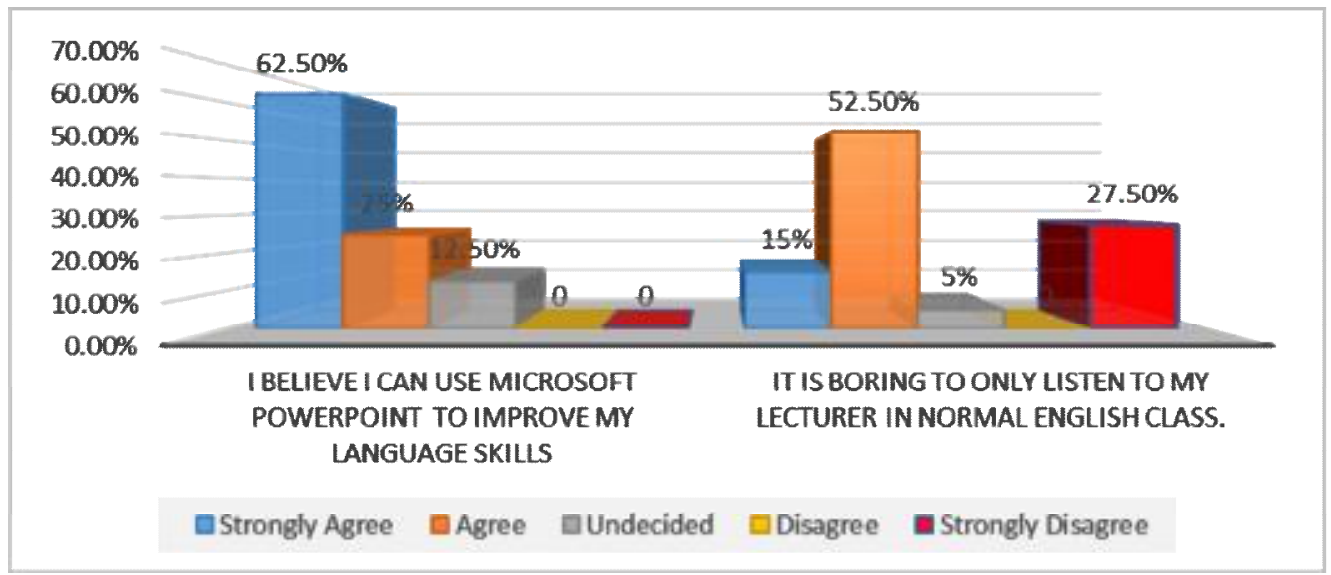

Figure 4.1 Participants’ Attitude about the Impact of Using of Microsoft PowerPoint 
4.5 Discussion of the Participants' Anxiety Level Findings

A low anxiety level was noticed among participants when $60 \%$ disagreed with the statement, "I become anxious when my teacher uses a Microsoft PowerPoint presentation".

However, there are problems that cause high anxiety for students. One example is when their Microsoft PowerPoint presentation does not work; almost all the respondents $(97.5 \%)$ were very disappointed when the presentation of the teacher does not work. Participants felt that training could be a factor that can reduce Anxiety since $75 \%$ replied that the training provided in the first LMD cycle reduced their anxiety.

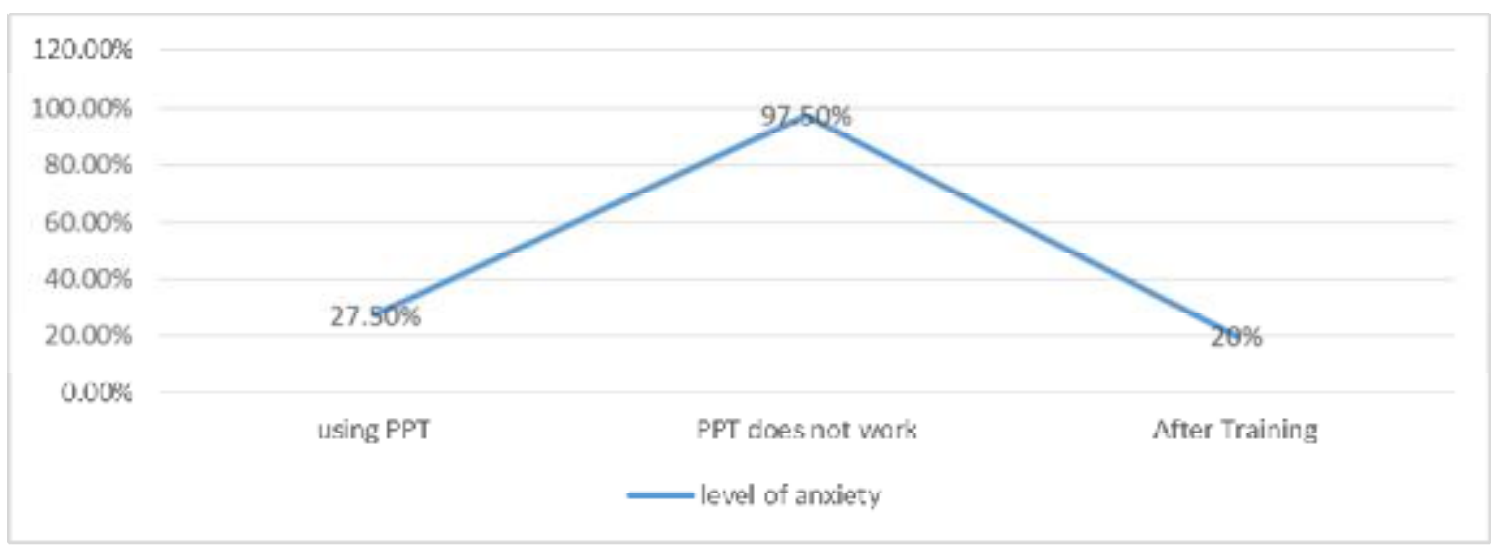

Figure 4.2 Level of participants' anxiety towards using Microsoft Power Point

\subsection{The Interview Results}

In order to back up the data obtained from the questionnaire, an interview was set out for 10 selected participants among those who completed the questionnaire.

All participants had a positive attitude when they present a work that requires PowerPoint. This may be due to the fact that participants have been used to it since some teachers already rely on this tool. Thus, they became more integrated in technology trend. One participants said "What makes PowerPoint attractive is not the tool itself, but the way it is used and the way its functions are gathered to emphasise on the most important elements of the lecture."

When asked if a PowerPoint presentation makes the respondents feel anxious, most of them said no, because they are motivated to associate technology with English learning. However, four participants replied yes to the same question but the reason of feeling anxious varied from one participant to another. One participant said "Yes, because sometimes there is no interaction between the teacher and learners " while another said:" Yes, because the setting of the tool takes a lot of time and sometimes we waste time while waiting for the teacher to get it set".

There was unanimity of respondents that Microsoft PowerPoint should be included in education and especially EFL classrooms for various reasons. One interviewee stated "Yes because visual aids help to learn better", another interviewee said: "yes because I can take notes without making mistakes". Another commented: "it includes clear pictures and sounds which helps to memorise the information."

\section{Summary of the Results}

This study was aimed to examine the attitude and anxiety of Master 2 students of didactics of English as a foreign language at Djillali Liabes University Sidi Bel Abbes Algeria when Microsoft PowerPoint is used in EFL classroom.

As it was pointed out by Fisher (2003), "PowerPoint has been in existence for many years, it has just begun to spread to schools and ESL classrooms... [and]...the reason for this delay is that technology requires hardware, which is relatively expensive.", it is no longer an excuse for Algerian teachers to avoid using technology in teaching since Algerian universities in general and Sidi Bel Abbes university in particular has already been provided with those tools. Furthermore, there can be also another determining fact shown in this study with the positive attitude of Master 2 students of didactics of English as a foreign language at Djillali Liabes University Sidi Bel Abbes towards the use of Microsoft PowerPoint in EFL classroom.

Given the results of a study conducted by Cobb (2002), it was found that ICT can enhance students' motivation and confidence in using the English language and can assist with language acquisition in ESOL students. It makes sense that the majority of participants showed a positive attitude towards using Microsoft Power Point to improve their English level and also the four language skills (listening, speaking writing and reading). This positive attitude is attributed to the fact that the tools provided by Microsoft PowerPoint facilitate their work and are more helpful in improving their language skills and also their computer skills. Moreover, the use of Microsoft PowerPoint generates a great learning atmosphere, which makes English lessons interesting. If students have positive attitudes towards using Microsoft PowerPoint to learn English, it is remotely inevitable that they will achieve higher proficiency level with the software. Having said this and based on those results, EFL students' attitude is positive when lessons are presented by Microsoft PowerPoint, which confirms the first hypothesis of this study. 
It is a common knowledge that anxiety in language classroom cannot be avoided or prevented. Yet, it was noticed low anxiety among the majority of EFL students but as in the case of this study, anxiety is still present. High anxiety can be caused by the failure of software sometimes when it is not working appropriately because of technicalities. However, it is possible to reduce anxiety and not completely eradicate it through ICT training. The findings of the current study were generally similar to those found by Valerie (2006) on her research on the effects of using ICT on EFL Malaysian students. Based on those results, EFL students are less anxious when lessons are presented by Microsoft Power Point, which confirms the second hypothesis.

\subsection{Pedagogical Implications}

The data obtained from this study revealed that by using ICT appropriately, it would help to improve the learning process for students learning English Foreign language.

First of all, This study already proved that students are interested in using Microsoft PowerPoint to learn English. Hence, all teachers could start using Microsoft PowerPoint in their English class since so far; only few teachers at the English department Djillali Liabes University are embracing this ICT tool. Either they can use it to teach or they can make it a part of student activity since they certainly need more opportunities. Moreover, teachers should take into consideration how the students like to learn because learning style differs from one learner to another. Educational technology is playing an important role in the teaching profession but it does not mean that teachers should be totally enslaved to the ICT tools. They can use Microsoft PowerPoint as a tool, not as a method. They can incorporate the use of technology to teach as a way to add variety into classroom procedures so students do not get bored. It could be a form of motivation for the students and also the teachers themselves.

\section{Conclusion}

The reason to choose this topic "The effects of using Microsoft PowerPoint on EFL learners" was mainly because of the awareness of the importance of ICT nowadays, its absence of using it at Algerian universities in general and especially at the department of foreign languages, Djillali Liabes University.

The main objective was to show the impact of using one of ICT tools such as Microsoft PowerPoint, on the EFL learners' attitude and anxiety. There is still a need for many studies that have to be done in order to determine the future of ICT in Algerian EFL classroom because Algeria is still consider left behind with modern technology especially in the educational field.

Having said this, the use of ICT in EFL classrooms offers significant advantage in language teaching learning; students can be more motivated and less anxious. Yet, PowerPoint is not the answer to all foreign language problems. What more is certain is that, when this tool is used considerately, it can increase learners' motivation, and therefore backing up the teacher to make his job less stressful and more efficient in order to achieve their objectives.

\section{References}

Amr Hamdy. (2007). ICT in Education in Algeria: Survey of ICT and Education in Africa: Algeria Country Report. Disick, R. S. (1972). Developing Positive Attitudes in Intermediate Foreign Language Classes. The Modern Language Journal. 56: 417-420

Hedge, T. (2000). Teaching and Learning in the Language Classroom. Oxford: Oxford University Press.

Noor Zainab Abdul Razak. (2005). Investigating Students' Motivational Orientation When Learning English in the ESL Classroom. In: Pandian, A., Chakravarthy, G., Kell, P. \& P. Kaur. Eds. Strategies \& Practices for Improving Learning and Literacy. Serdang: Universiti Putra Malaysia Press. 32-39.

Spielberger, C.D., \& Auerbach, S.M. (1972). The Assessment of State and Trait Anxiety with The Rorschach Test. Journal of Personality Assessment, 36, 314-335.

Steve Kennewell (2004). Meeting the Standards in Using ICT for Secondary Teaching. Routledge Falmer 11 New Fetter Lane, London

Thomas, K. (1971). Attitudes and Behaviour. In: Penguin Psychology Readings. Baltimore: Penguin Books.

Valerie Chan Sue Lin (2007). The Use of Microsoft ${ }^{\circledR}$ PowerPoint ${ }^{\circledR}$ To Learn English Language among Uitm PreDiploma Students. Universiti Teknologi Malaysia.

\section{Web References}

Cobb, K. J. (2002). Facilitating Second Language Acquisition Through Computer Assisted Language Learning. Action Research Exchange. 1 (1). Retrieved 20 May 2012, http://chiron.valdosta.edu/are/Artmanscrpt/ vollno1/cobb_am.pdf Fisher, D. L. (2003). Motivation as a contributing factor in second language acquisition. The Internet TESL Journal. IX (4). Retrieved 20 May 2012 from http://iteslj.org/Techniques/Fisher-PowerPoint.html

Koba, N., Ogawa, N. \& Wilkinson, D. (2000). Using the Community Language Learning Approach to Cope with Language Anxiety. The Internet TESL Journal. VI (11). Retrieved 20 ${ }^{\text {th }}$ May 2012, http://iteslj.org/Articles/KobaCLL.html

Radanov, L. (2008). PowerPoint presentations in EFL classroom - "Power point is" or a challenge? Retrieved $25^{\text {th }}$ May 2012 from www.britishcouncil.org/serbia-elta-newsletter-march powerpoint_presentations_in_efl_classroom.doc

Steele, S \& Johnson, J. (n.d). PowerPoint in the classroom. Retrieved $25^{\text {th }}$ May 2012 from http://www.tiger.towson.edu/users/sstee12/researchpaper.htm

Von Wörde, R. (2003). Students' Perspectives on Foreign Language Anxiety. Inquiry. 8 (1). Retrieved $1^{\text {st }}$ May 2013 , http://www.vccaedu.org/inquiry/ inquiry-spring2003/i-81-worde.html 